\title{
Meningkatkan Kemampuan Motorik Halus Anak melalui Kegiatan Menulis di Atas Pasir
}

\section{(Improving Children's Fine Motor Skill through Writing Activity on the Sand)}

\author{
Tiara Erlianda ${ }^{1}$, Ahmad Fauzi ${ }^{2}$, Khairul Amri ${ }^{3}$ \\ ${ }^{13}$ Pendidikan Islam Anak Usia Dini, Institut Agama Islam Negeri Langsa \\ 2 Pendidikan Bahasa Arab, UIN Ar-Raniry \\ 1'tiaraerlianda5@gmail.com, ${ }^{2}$ ahmamfauzi@gmail.com, ${ }^{3} \mathrm{khairul}$ amri1984@yahoo.com
}

$\begin{array}{ccc}\text { First received: } & \text { Revised: } & \text { Final Accepted: } \\ \text { 27 November 2019 } & \text { 16 December 2019 } & \text { 21 December 2019 }\end{array}$

\begin{abstract}
The fine motor skills of children in the group B2 of TK Islam Terpadu Darul Mukhlishin are still lack. It can be seen from the results of the letters written by the child that is not in accordance with the example given by the teacher. The study aims to an increase in children's fine motor skills through writing activities on the sand in TK Islam Terpadu Darul Mukhlishin. This type of research is a classroom action research conducted in 2 cycles. This research uses a quantitative approach with descriptive statistical methods. Data collection techniques used were observation, interview and tests. The research instrument used observation sheets, interview sheets and tests. Data analysis techniques used descriptive and inferential statistics using t-test. The results showed that fine motor skills achieved by children in group B2 before the action reached $30.25 \%$. In the first cycle of action reached $61.125 \%$ while in the second cycle of action reached $91.5 \%$. In testing hypotheses through $t$-test with a significant level of $5 \%$, it show that the value of $\mathrm{t}$-count $\geq \mathrm{t}$-table is $22.23 \geq 2.093$, it can be concluded that $\mathrm{H}_{0}$ is rejected and $\mathrm{H}_{\mathrm{a}}$ is accepted, namely writing on sand can improve children's fine motor skills in group B2 of TK Islam Terpadu Darul Mukhlishin.
\end{abstract}

Keywords: Fine Motor Skill, Writing Activity, Playing Sand

\begin{abstract}
Abstrak
Kemampuan motorik halus anak kelompok B2 TK Islam Terpadu Darul Mukhlishin masih sangat kurang, hal ini dapat dilihat dari hasil huruf yang ditulis anak tidak sesuai dengan contoh yang diberikan guru. Penelitian ini bertujuan untuk meningkatkan kemampuan motorik halus anak melalui kegiatan menulis di atas pasir pada TK Islam Terpadu Darul Mukhlishin. Jenis penelitian yang digunakan adalah penelitian tindakan kelas yang dilakukan dalam 2 siklus. Penelitian ini menggunakan pendekatan kuantitatif dengan metode statistik deskriptif. Teknik pengumpulan data yang digunakan ialah observasi, wawancara dan test. Instrument penelitian menggunakan lembar observasi, lembar wawancara dan test. Teknik analisis data menggunakan statistik deskriptif dan inferensial menggunakan uji-t. Hasil penelitian menunjukkan Kemampuan motorik halus yang dicapai anak kelompok B2 sebelum tindakan mencapai 30,25\%. Pada tindakan siklus I mencapai 61.125, sedangkan pada tindakan siklus II mencapai $91.5 \%$. Pada pengujian hipotesis melalui uji-t dengan taraf signifikan 5\% memperlihatkan bahwa nilai thitung $\geq t_{\text {tabel }}$ yaitu $22.23 \geq 2.093$. Maka dapat disimpulkan bahwa $\mathrm{H}_{\mathrm{o}}$ ditolak dan $\mathrm{H}_{\mathrm{a}}$ diterima yaitu kegiatan menulis di atas pasir dapat meningkatkan kemampuan motorik halus anak pada TK Islam Terpadu Darul Mukhlishin kelompok B2.
\end{abstract}

Kata Kunci: Kemampuan Motorik Halus, Kegiatan Menulis, Bermain Pasir 


\section{PENDAHULUAN}

Undang-undang Nomor 20 Tahun 2003 tentang Sistem Pendidikan Nasional Bab 1 Pasal 1 Butir 14 menyatakan bahwa pendidikan anak usia dini adalah suatu upaya pembinaan yang ditujukan kepada anak sejak lahir sampai dengan usia 6 tahun yang dilakukan melalui pemberian rangsangan pendidikan untuk membantu pertumbuhan dan perkembangan jasmani dan rohani agar anak memiliki kesiapan dalam memasuki pendidikan lebih lanjut.

Pendidikan anak usia dini merupakan salah satu bentuk penyelenggaraan penddikan yang menitikberatkan pada peletakan dasar kearah pertumbuhan dan perkembangan fisik, kecerdasan, sosio emosional, bahasa dan komunikasi sesuai dengan keunikan dan tahap-tahap perkembangan yang di lalui oleh anak usia dini.

Howard Gardner mengatakan bahwa pada hakikatnya setiap anak adalah anak yang cerdas. Kecerdasan bukan hanya dipandang dari IQ saja, tetapi ada kecerdasan lain yang akan mengantarkan anak pada kesuksesan. Menurut Gardner (2003) potensi kecerdasan manusia dapat dirumuskan kedalam 8 jenis kecerdasan majemuk yang meliputi: kecerdasan bahasa (kecerdasan dalam mengelola katakata), kecerdasan logika (kecerdasan dalam bidang angka dan alasan logis), kecerdasan spasial (gambar), kecerdasan kinestetik (kecerdasan music dan kecerdasan gerak), intrapersonal (kecerdasan diri), interpersonal (kecerdasan bergaul), dan naturalist (kecerdasan alami).

Taraf berfikir anak pada usia 5-6 tahun adalah menggambar sesuai dengan gagasannya, meniru bentuk, melakukan eksplorasi dengan berbagai media dan kegiatan, menggunakan alat tulis dan alat makan dengan benar, menggunting sesuai dengan pola, menempel gambar dengan tepat, dan mengekspresikan diri melalui gerakan menggambar secara rinci.

Kemampuan motorik halus adalah kemampuan yang berhubungan dengan keterampilan fisik yang melibatkan otot kecil dan koordinasi mata-tangan. Saraf motorik halus ini dapat dilatih dan dikembangkan melalui kegiatan dan rangsangan yang kontinu secara rutin.

Menurut Santrock (1995), pada usia 4 tahun, koordinasi motorik halus anak-anak telah semakin meningkat dan menjadi lebih tepat dan pada usia 5 tahun koordinasi motorik halus akan semakin meningkat. Saputra dan Rudyanto mengatakan bahwa motorik halus adalah kemampuan anak beraktivitas dengan menggunakan otot-otot halus (kecil) seperti menulis, meremas, menggambar, menggenggam, menyusun balok dan memasukkan kelereng.

Dapat disimpulkan bahwa kemampuan motorik halus adalah kemampuan anak dalam menggerakkan otot-otot kecilnya dalam melakukan aktivitas sederhana yang tidak membutuhkan banyak tenaga.

Kemampuan motorik halus adalah kemampuan manipulasi halus yang melibatkan penggunaan tangan dan jari secara tepat seperti dalam kegiatan menulis dan menggambar. Kemampuan motorik halus fokus pada kemampuan koordinasi tangan dan mata. Pada umumnya, anak akan menunjukkan kemampuan perilaku kontrol motorik halus sederhana pada usia 4-6 tahun. Kemampuan motorik halus semakin meningkat pada usia 5-12 tahun yang ditandai dengan meningkatnya keterampilan motorik halus secara signifikan dibagian pergelangan tangannya. 
Hurlock (1998) mengemukakan bahwa perkembangan motorik anak adalah suatu proses kematangan yang berhubungan dengan aspek deferensial bentuk atau fungsi termasuk perubahan sosial emosional. Proses motorik adalah gerakan yang langsung melibatkan otot untuk bergerak dan proses persyaratan yang menjadikan seseorang mampu menggerakkan anggota tubunhya (tangan, kaki dan anggota tubuhya).

Menurut Saputra (2005) tujuan pengembangan motorik halus anak yaitu mampu memfungsikan otot-otot kecil seperti gerakan jari tangan, mampu mengkoordinasikan kecepatan tangan dengan mata, dan mampu mengendalikan emosi.

Suyanto (2005) motorik halus berfungsi untuk melakukan gerakangerakan bagian tubuh yang lebih spesifik, seperti menulis, melipat, merangkai, mengancing baju, menali sepatu dan menggunting.

Media yang digunakan untuk meningkatkan motorik halus anak dapat berupa benda-benda alam seperti daun dan bunga-bunga, serta barang bekas (Sidabutar \& Siahaan, 2019; Maghfirah, 2019)

Hurlock dalam Mudjito (2007) mencatat beberapa alasan tentang fungsi perkembangan motorik bagi konstelasi perkembangan individu, yaitu melalui keterampilan motorik anak dapat menghibur dirinya dan memperoleh perasaan senang, melalui keterampilan motorik anak dapat bergerak dari satu tempat ketempat lainnya dan dapat berbuat sendiri untuk dirinya. Kondisi ini akan menunjang perkembangan rasa percaya diri, melalui keterampilan motorik anak dapat menyesuaikan dirinya dengan lingkungan sekolah. Pada usia taman kanak-kanak anak sudah dapat dilatih menggambar, melukis, baris-berbaris, dan persiapan menulis.

Karakteristik perkembangan motorik halus anak dapat dijelaskan dalam Departemen Pendidikan Nasional (2007) sebagai berikut:

a. Pada saat anak usia tiga tahun kemampuan gerakan halus pada masi bayi. Meskipun anak pada saat ini sudah mampu menjumput benda dengan menggunakan jempol dan jari telunjuknya tetapi gerakan itu sendiri masih kikuk.

b. Pada usia empat tahun koordinasi motorik halus anak sudah lebih sempurna lagi tangan, lengan, dan tubuh bergerak dibawah koordinasi mata. Anak juga telah mampu membuat dan melaksanakan kegiatan yang lebih majemuk, seperti kegiatan proyek.

c. Pada akhir masa kanak-kanak usia enam tahun ia telah belajar bagaimana menggunakan jari jemarinya dan pergelangan tangannya untuk menggerakkan ujung pensilnya.

Menulis adalah tahap akhir pembelajaran literacy (menulis). Pembelajaran menulis baru boleh diberikan ketika semua bentuk stimulasi telah diberikan.Stimulasi perkembangan bahasa yaitu mengenal huruf, membaca dan menulis. Secara teoritis sebelum belajar menulis anak-anak harus melalui tahaptahap, seperti menyimak, mendengar, dan bicara. Setelah semua tahapan ini dikuasai, barulah pembelajaran menulis boleh dimulai (Suyadi 2009).

Menurut Suyadi (2009) Keseimbangan antara membaca dan menulis akan sangat membantu anak-anak menuangkan ide dan gagasannya dalam bentuk tulisan, seperti surat, puisi, pantun, dan lain-lain. Sehingga anak tidak hanya pandai bercerita saja, tetapi juga pandai menulis. 
Anak usia dini tidak perlu dipaksakan untuk dapat menuliskan ide-ide yang sangat abstrak, tetapi cukup menulis namanya sendiri, nama ayahnya, ibunya, kakek, nenek, dan lain sebagainya.

Kegiatan menulis dasar dapat dimulai saat anak menunjukkan perilaku seperti mencoret-coret buku atau dinding, kondisi tersebut menunjukkan berfungsinya sel-sel otak yang perlu dirangsang supaya berkembang secara optimal (Depdiknas 2007).

Soemarmo

menjelaskan

Markam menulis
(1987) adalah mengungkapkan bahasa dalam bentuk simbol dan gambar dan merupakan aktivitas kompleks yang mencakup gerakan lengan, tangan, jari dan mata secara terintegrasi. proses menulis pada hakikatnya merupakan suatu proses neurofisiologis.

Menurut Webster dalam Atkinson (2009) kemampuan menulis bagi anak usia 5-6 tahun diartikan sebagai suatu kegiatan membuat pola atau menuliskan kata-kata, huruf-huruf ataupun simbol-simbol pada suatu permukaan dengan memotong, mengukur atau menandai dengan pena.

Kemampuan menulis pada anak Taman Kanak-kanak (TK) meliputi: kemampuan dan keterampilan memegang alat tulis, membuka dan menutup buku, mengenal bentuk huruf dan perbedaan bunyi, mengenal rangkaian pola, menggunakan penghapus ketika harus menghapus gambar atau tulisan, cara duduk yang benar, kemampuan membuat coretan, serta menggambar garis lurus, garis miring, garis lengkung, segitiga, segiempat dan lingkaran.

Gibson dalam Suyanto

menerangkan bahwa pada usia 14 bulan anak akan membuat coretan jika diberikan kertas dan alat tulis sedangkan pada usia 18 bulan anak akan membuat coretan atas inisiatif sendiri. Kegiatan tersebut terus berlangsung dan semakin jelas perbedaannya antara menulis dengan menggambar. Apabila dibimbing dengan baik, maka pada usia 30 bulan (2,5 tahun) anak sudah dapat menulis namanya sendiri.

Adapun prinsip-prinsip yang perlu diperhatikan dalam menumbuhkan keinginan menulis anak menurut Departemen Pendidikan Nasional (2000) di antaranya adalah : (a) Prinsip penggunaan tanda atau simbol yaitu guru memberi kesempatan yang banyak pada anak untuk melatih kelenturan motorik halus anak. (b) Prinsip pengulangan yaitu memberikan latihan pengulangan, (c) Prinsip keluwesan yaitu guru memperkenalkan tulisan pertama kali pada anak berupa simbol atau tanda yang dekat dan dikenal anak, (d) Prinsip pengungkapan yaitu memberikan kesempatan pada anak untuk mengungkapkan berbagai pengalamannya dengan tulisan yang telah dibuatnya, (e) Prinsip mencontoh yaitu guru sering mengulang berbagai contoh tulisan atau kata dengan konteks yang sama, (f) Prinsip penguatan yaitu guru memberikan penguatan berupa penghargaan atau pujian terhadap hasil tulisan anak.

Dhieni (2008) menyatakan bahwa kemampuan menulis dipengaruhi oleh beberapa hal seperti berikut: (a) Perhatian dan pengenalan terhadap huruf, (b) Kemampuan motorik halus, (c) Kemampian koordinasi gerakan tangan/jari yang dikoordinasikan dengan mata dan perasaan, (d) Kemampuan mengenal kembali apa yang ditulis dan didengar, (e) Kemampuan menempatkan posisi tubuh dalam ruang atau posisi alat gerak terhadap tubuh.

Pentingnya kemampuan menulis bagi anak usia dini yaitu untuk mengembangkan perkembangan bahasa 
anak, karena kegiatan menulis mempunyai hubungan yang erat dengan membaca.

Manfaat menulis bagi anak usia dini yaitu untuk melatih kesabaran anak, untuk belajar merangkai kata, untuk meningkatkan kreativitas anak, imajinasi anak dan sensorimotor anak.

Anak yang perkembangan motoriknya belum matang maka akan mengalami kesulitan dalam menulis, tulisannya tidak jelas, terputus-putus, tidak mengikuti garis atau memerlukan waktu yang lama untuk menuliskan sebuah kata atau kalimat.

Pemberian stimulasi motorik pada anak dapat melalui berbagai cara, salah satunya dengan menggunakan pasir. Pasir merupakan benda yang mudah ditemukan, dipegang dan digenggam. Syaraf taktil pada jemari anak akan aktif ketika anak bersentuhan langsung dengan pasir. Hal ini dapat menstimulasi motorik halusnya sehingga kemampuan menulis permulaan pada anak usia dini dapat berkembang.

Pasir merupakan salah satu media pembelajaran yang dapat menimbulkan semangat, motivasi peserta didik, melatih kepercayaan diri anak dan dapat membangun kesenangan belajar anak. Pasir adalah media yang sangat menyenangkan dan mengasyikkan bagi anak dengan teksturnya yang lembut dapat dipegang oleh anak, dan anak akan merasakan sensasi pada jari anak pada sentuhan-sentuhan kulit anak seperti merasakan kasar atau lembutnya pasir, lengket, kering dan basah. Pasir juga dapat mengasah kemampuan psikomotorik, kognitif, sensoris, sosial emosiosal dan bahasa.

Penelitian ini dilakukan untuk meningkatkan kemampuan motorik halus anak melalui kegiatan menulis di atas pasir. Dalam penelitian ini, merupakan kombinasi dari aspek bahasa dan motorik halus. Dimana kemampuan menulis dipengaruhi oleh faktor perkembangan motorik halus yang sudah matang dan aspek bahasa dimana kemampuan menulis merupakan integrasi dari proses berpikir kritis yang menerima, mengolah, mempersepsikan dan menalar suatu informasi yang kemudian akan di ekspresikan ke dalam bentuk tulisan dengan tujuan untuk menyampaikan ide / gagasan, pemikiran dan mengungkapkan perasaan.

Hubungan penerapan pasir terhadap kemampuan motorik halus anak adalah ketika anak melakukan kegiatan mencoretcoret, belajar membuat huruf ataupun belajar meniru huruf di atas pasir dengan jari tangan, secara tidak langsung syaraf taktil yang ada apada ujung jari anak juga ikut aktif bekerja. Pada saat itulah koordinasi otot tangan dan jari/kelenturan anak bekerja. Gerakan jari di atas permukaaan pasir merupakan gerakan latihan penguasaan keterampilan motorik halus anak sehingga melalui kegiatan menulis di atas pasir dapat mengoptimalkan kemampuan motorik halus anak. Maka kesimpulannya adalah matangnya kemampuan motorik halus anak, matangnya pemahaman anak terhadap huruf dapat berpengaruh terhadap kemampuan menulis anak.

Di balik kesenangan anak-anak meremas, mengaduk, mencetak, menggambar, atau menulis di atas pasir, tersimpan banyak manfaat bagi perkembangan mereka. Adapun manfaat dari bermain pasir bagi anak-anak antara lain: (a) Psikomotorik. Anak-anak bermain pasir menggunakan jari, tangan, lengan mereka, dan melatih koordinasi diantaranya. Menggali pasir menggunakan sekop, membentuk menggunakan berbagai cetakan melatih otot-otot, koordinasi mata dan motorik halus. (b) Kognitif. Bermain pasir dapat menambah pengetahuan anak mengenai berbagai bentuk, ukuran, perubahan wujud sehingga dapat 
meningkatkan kecerdasan anak. (c) Sensoris. Bermain pasir dapat merangsang anak untuk mengasah kemampuan sensoris melalui sentuhan kulitnya. (d) Sosial. Bermain pasir bersama teman akan meningkatkan kemampuan sosialnya untuk saling berbagi, membantu, melakukan kompromi, meminta sesuatu, menawarkan mainan, dan juga membangun hubungan persahabatan. (e) Bahasa. Saat bermain bersama teman sebaya, komunikasi verbal yang terjadi dua arah akan semakin memperkaya kosakata dan memperlancar bicara anak. (f) Untuk melatih syaraf taktil anak, karena dengan teksturnya pasir dapat menghidupkan syaraf taktil anak.

Manfaat bermain pasir bagi anak yaitu dapat melatih kemampuan sensori anak dengan memberikan pengalaman sensori pada anak, melatih kreativitas dan imakinasi anak, melatih sosialisasi anak, melatih fisik anak dan meredakan emosi anak.

Tahap kegiatan menulis diatas pasir dapat dimulai dengan cara yaitu: (a) Menyiapkan pasir untuk anak-anak, bila lahan sempit pasir dapat diletakkan di baskom atau tempat terbuka. (b) Sebelum belajar menulis berlangsung permukaan pasir diratakan. (c) Pasir dibuat dengan dua tempat ada yang pasir basah dan pasir kering, sehingga hasil tulisan anak dapat terlihat dengan jelas. (d) Sebelum anak memulai untuk menulis orangtua atau guru harus memberikan contoh terlebih dahulu kepada anak cara menulis huruf atau angka diatas pasir dengan jari.

Kelebihan dalam kegiatan menulis diatas pasir ini yaitu: (a) Memberikan sensasi pada jari sehingga dapat merasakan kontrol gerakan jarinya dan membentuk konsep gerakan membuat huruf. (b) Kegiatan menulis diatas pasir juga mengajarkan konsep sensorimotor, kreativitas, kognitif, psikomotorik dan sosialisasi.

Kekurangan dalam kegiatan menulis diatas pasir yaitu: (a) Bermain kotor dan terkadang anak merasa jijik dan geli karena pasir yang digunakan sebagai media lengket pada jari- jemari anak. (b) Untuk media pasir anak harus dikontrol jangan sampai pasir masuk ke dalam mata anak.

\section{METODE}

Jenis penelitian yang digunakan adalah penelitian tindakan kelas (PTK) dengan model Kemmis dan Taggart. Peneliti disini sebagai guru yang diamati oleh teman sejawat atau guru kelas. Sebagaimana yang berperan sebagai gurur adalah peneliti dengan tujuan untuk meningkatkan hasil belajar kemampuan motorik halus anak melalui kegiatan menulis di atas pasir.

Pendekatan yang digunakan dalam penelitian ini yaitu pendekatan kuantitatif. Dimana pendekatan kuantitatif merupakan penelitian yang analisisnya lebih fokus pada data-data angka yang di olah dengan menggunakan metode statistika (Sugiyono 2004:15). Data kuantitatif adalah data yang berwujud angka-angka hasil perhitungan dapat diproses dengan cara dijumlahkan dan dibandingkan sehingga dapat diperoleh persentase, misalnya tes hasil. Tes hasil belajar dalam penelitian ini adalah alat ukur mengukur hasil belajar anak setelah menggunakan media pasir.

Populasi dalam penelitian ini adalah anak-anak kelas B2 TK Islam Terpadu Darul Mukhlishin yang terdiri dari 20 anak, 10 anak laki-laki dan 10 anak perempuan. Pengambilan sampel dalam penelitian ini yaitu dengan sampling jenuh, di kelas B2 TK Islam Terpadu Darul Mukhlishin dengan jumlah siswa 20 anak, 10 anak laki-laki dan 10 anak perempuan. 
Metode penelitian yang digunakan adalah metode statistik deskriptif. Teknik pengumpulan data yang digunakan dalam penelitian ini adalah:

a. Observasi. Observasi dalam penelitian ini dilakukan oleh peneliti dan dibantu oleh guru sebagai pengamat dalam melihat aktivitas-aktivitas siswa ketika proses pembelajaran berlangsung. Observasi ini dikembangkan dengan tujuan untuk mengukur kemampuan motorik halus anak dalam kegiatan menulis di atas pasir yang sesuai dengan indikator penilaian.

b. Wawancara, yaitu peneliti mewawancarai dua guru di kelompok B2 TK Islam Terpadu Darul Mukhlishin yang masingmasing guru memiliki pendapat yang berbeda-beda.

c. Tes, terdiri atas (a) Pre-tes merupakan tes yang dilakukan untuk mengukur kemampuan motorik halus anak melalui kegiatan menulis di atas pasir. (b) Post-tes merupakan tes yang dilakukan setelah akhir pembelajaran. Tes ini bertujuan untuk mengetahui sampai dimana pencapaian anak terhadap kegiatan menulis di atas pasir. Tes ini diberikan kepada siswa secara individual, pemberiannya ditujukan untuk mengukur peningkatan kemampuan motorik halus anak. Tes yang digunakan adalah tes soal dengan kegiatan menulis di atas pasir yang terdiri dari 5 butir kegiatan. Materi yang diujikan adalah materi pokok kegiatan menulis di atas pasir. Sebelum tes diberikan, terlebih dahulu tes diujicobakan untuk mengetahui validitas, reliabilitas instrument $(\mathrm{r}=$ $0.653)$.

Rumus menentukan tingkat keberhasilan anak dengan mempersentase data yang diperoleh yaitu sebagai berikut :

$$
p=\frac{f}{N} X 100 \%
$$

Keterangan :

$P$ : angka persentase

F : frekuensi yang sedang dicari persentasenya

$\mathrm{N}$ : jumlah frekuensi/banyaknya individu seluruhnya

Suharsimi Arikunto

(2010:44) menginterpretasikan skala keberhasilan menjadi empat tingkatan yaitu :

a) Kategori baik (Berkembang Sangat Baik/BSB) apabila hasil penilaian kemampuan motorik halus yang dicapai anak antara 76-100\%

b) Kategori cukup (Berkembang Sesuai Harapan/BSH) apabila hasil penilaian kemampuan motorik halus yang dicapai anak antara $56-75 \%$

c) Kategori kurang (Mulai Berkembang/MB) apabila hasil penilaian kemampuan motorik halus yang dicapai anak antara $41-55 \%$

d) Kategori belum baik (Belum Berkembang/BB) apabila hasil penilaian kemampuan motorik halus yang dicapai anak antara 0$40 \%$.

\section{HASIL TEMUAN DAN PEMBAHASAN}

Kemampuan motorik halus anak kelompok B2 TK Islam Terpadu Darul Mukhlishin masih sangat rendah. Hal ini dapat dilihat saat peneliti melakukan 
observasi disaat anak sedang belajar. Pada saat kegiatan pembelajaran berlangsung, peneliti melihat ada beberapa anak yang motorik halusnya belum terlatih. Hal ini dapat dilihat pada saat anak melakukan kegiatan, anak masih kaku dalam menggerakkan jari tangannya, anak dapat melakukan segala aktivitas apabila kemampuan motorik halus anak sudah berkembang. Anak masih mengalami kesulitan dalam menulis bahkan dalam memegang pensil pun anak masih kaku dalam menggerakkan pensil untuk menulis.

Begitu rendahnya kemampuan motorik halus anak dalam menulis pada TK Islam Terpadu Darul Mukhlishin. Hal ini diketahui dari hasil huruf yang ditulis anak tidak sesuai dengan contoh yang diberikan oleh guru. Kemudian disaat anak sedang menulis anak kurang konsentrasi pada pekerjaannya sehingga anak tidak dapat mengontrol emosinya bahkan pandangan anak juga tidak fokus dalam menulis. Begitu rendahnya kemampuan motorik halus anak dalam menulis pada TK Islam Terpadu Darul Mukhlishin. Hal ini dapat dilihat dari hasil pretes anak yang hanya beberapa anak saja yang tuntas dalam kegiatan menulis.

Peningkatan kemampuan motorik halus pada anak sangat penting untuk dikembangkan. Hal ini dikarenakan kemampuan motorik halus anak dapat membantu anak dalam melatih kelenturan otot jari tangan anak, sehingga dapat mempermudah anak dalam berpakaian, mempermudah segala aktivitas anak tanpa memerlukan bantuan dari orang lain, dan dapat membuat anak menjadi lebih mandiri.

Pertama kali anak mulai belajar melalui kegiatan menulis di atas pasir anak sangat senang dan bersemangat. Hanya satu atau dua orang anak yang merasakan jijik disaat menulis di atas pasir. Akan tetap ini tidak membuat anak menyerah, anak tersebut terus mengikuti kegiatan yang berlangsung. Hal ini disebabkan karena disaat anak menulis di atas pasir anak merasakan sensasi pada jari tangannya, anak dapat merasakan halus atau kasarnya pasir tersebut. Pasir dapat merangsang motorik halus anak karena pasir bersifat multi fungsi yang dapat digunakan sesuai keinginan anak. Jadi anak dapat melakukan apa saja melalui pasir tersebut.

Setelah peneliti mengarahkan kepada anak-anak bahwa selama beberapa hari kedepan anak-anak akan belajar menulis di atas pasir terus-menerus. Dan reaksi anakanak pun sangat baik, mereka bersemangat sampai tidak ingin pulang karena ingin terus menerus bermain pasir.

Tahap pertama, peneliti menjelaskan apa yang harus dilakukan anak dalam proses pembelajaran yang berlangsung. Pada tahap ini peneliti mengenalkan huruf abjad terlebih dahulu kepada anak, kemudian peneliti meminta anak untuk menuliskan huruf abjad. Setelah anak mampu mengenal dan menulis huruf abjad, barulah peneliti meminta anak untuk menulis nama dari huruf awal nama masing-masing anak. Disaat anak sedang menulis, peneliti mulai menilai kemampuan motorik halus anak tersebut. Ada beberapa anak yang peneliti lihat, anak tersebut mengenal huruf abjad, akan tetapi mereka masih kaku dalam menggerakkan jari tangannya untuk menulis huruf abjad tersebut. Setelah peneliti membimbing dan terus melatih serta merangsang kemampuan motorik halus anak secara perlahan, maka terjadi perubahan pada diri anak, kemampuan motorik halus anak mulai terlatih secara perlahan.

Tahap kedua, peneliti memberikan arahan tentang kegiatan pembelajaran 
selanjutnya. Pada tahap ini, peneliti mengajak anak untuk membuat suku kata sederhana, seperti kata "ibu", dan "ayah". Peneliti memberikan contoh terlebih dahulu kepada anak, sambil mengajak anak bernyanyi huruf abjad. Setelah itu peneliti bertanya kepada anak, kata sederhana dari kata "ibu" terdiri dari huruf apa saja ya ?, hal ini dilakukan peneliti untuk melihat kemampuan anak dalam mengenal huruf. Kemudian peneliti meminta anak untuk maju kedepan bagi anak yang mengetahui huruf dari suku kata sedehana tersebut. Dan dalam kegiatan semua anak berlomba-lomba untuk maju kedepan agar dapat membuat suku kata yang sederhana. Dari kegiatan ni mengajarkan anak disiplin dan mengantri, karna harus menungguu giliran untuk dapat membuat suku kata sederhana.

Setelah pembelajaran suku kata tersebut selesai, baru lah masuk ke materi lain yaitu menggabungkan 5 huruf menjadi satu kata yang bermakna, seperti kata "bunda", "nenek" dan "kakek". Dalam materi ini duduk secara berkelompok yaitu berjumlah 5 orang. Masing-masing anak mengambil satu huruf yang berbeda, kemudian dari huruf yang berbeda tersebut di gabungkan menjadi satu kata yang bermakna. Nah dalam kegiatan ini, anak-anak sangat bersemangat dan ceria, karna disaat menggabungkan huruf tersebut, anak membutuhkan kerja sama dan kekompakan agar bisa menggabungkan kata dengan benar.

Dalam melatih kemampuan motorik halus anak memang tidak mudah, untuk melatih dan mencapai semuanya kita sebagai guru harus memiliki kesabaran yang ekstra dan perhatian yang luar biasa agar apa yang kita inginkan tercapai dengan baik, kita sebagai guru juga harus memberi pujian dan motivasi kepada anak terhadap hasil yang dicapai anak, walaupun hasil yang diperoleh anak tidak memuaskan.

Setelah melakukan proses pembelajaran melalui kegiatan menulis di atas pasir pada anak kelompok B2 TK Islam Terpadu Darul Mukhlishin maka semakin hari semakin terdapat peningkatan dalam kemampuan motorik halus anak. Hal ini disebabkan karena kelenturan otot jari jemari anak mulai berkembang dan terlatih sedikit demi sedikit. Kelenturan otot jari tangan anak sudah nampak berkembang hal ini dapat dilihat saat anak menggerakkan jarinya ketika menulis di atas pasir jari jemari anak sudah tidak kaku lagi saat menulis di atas pasir.

Kemampuan motorik halus sebelum tindakan yang dicapai anak Kelompok B2, dapat dideskripsikan bahwa kemampuan motorik halus sebelum tindakan, baru mencapai $30.25 \%$ dengan total skor 121 . Berdasarkan hasil tersebut dapat diketahui bahwa kemampuan awal motorik halus anak belum berkembang dengan baik. Hasil persentase pencapaian kemampuan motorik halus anak baru mencapai $30.25 \%$ dengan kategori belum baik atau Belum Berkembang (BB).

Berdasarkan hasil yang dicapai pada tindakan Siklus I, kemampuan motorik halus anak kelompok B2 pada pertemuan pertama, skor yang dicapai adalah 232 atau $60.75 \%$. Pada pertemuan kedua, skor yang dicapai adalah 246 atau 61.50\%. Dari hasil tersebut diketahui rata-rata kemampuan motorik halus anak kelompok B2 pada tindakan Siklus I skornya mencapai 239 atau $61.125 \%$ (Mulai Berkembang/MB). Hasil persentase pencapaian kemampuan motorik halus anak pada siklus I mencapai $61.125 \%$ dengan kategori cukup (Berkembang Sesuai Harapan/BSH). 
kemampuan motorik halus anak kelompok B2 TK Islam Terpadu Darul Mukhlishin, menunjukkan adanya peningkatan dari sebelum tindakan ke tindakan Siklus I. kemampuan motorik halus sebelum tindakan, mencapai skor 121 atau $30,25 \%$. Pada siklus I mencapai skor 239 atau 61.125\%. Peningkatan dari sebelum tindakan ke tindakan siklus I mencapai skor 118 atau $30.875 \%$.

Berdasarkan hasil yang dicapai pada tindakan Siklus II, kemampuan motorik halus anak kelompok B2 pada pertemuan pertama, skor yang dicapai adalah 350 atau $87.25 \%$. Pada pertemuan kedua, skor yang dicapai adalah 383 atau $95.75 \%$.

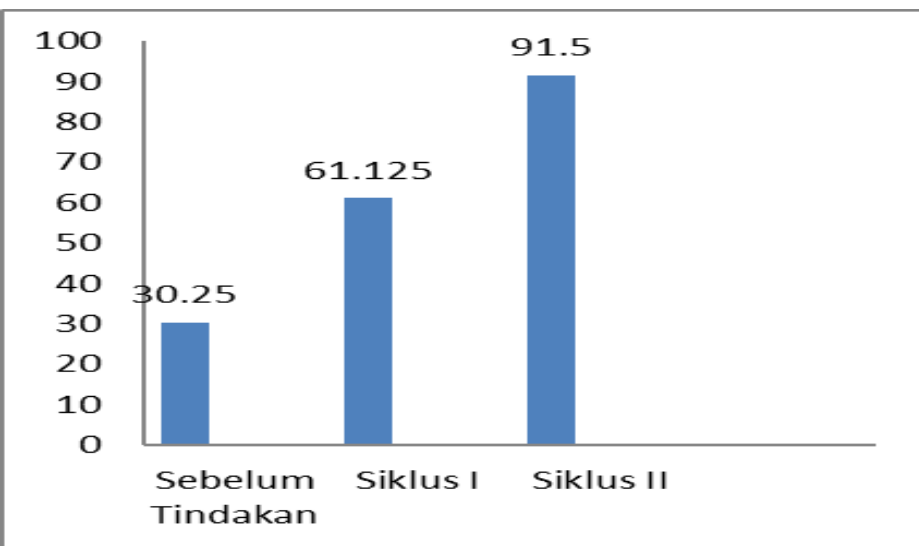

Gambar 1. Peningkatan Kemampuan Motorik Halus Anak Kelas B2 dari Sebelum Tindakan ke Siklus I dan Siklus II

Berdasarkan gambar 1 grafik diatas dapat diketahui bahwa kemampuan motorik halus yang dicapai anak kelompok B2 sebelum tindakan mencapai 30.25\% dengan kategori Belum Baik (Belum Berkembang). Pada tindakan siklus I mencapai $61.125 \%$ dengan kategori Cukup (Berkembang Sesuai Harapan). Pada tindakan siklus II mencapai $91.5 \%$ dengan kategori Baik (Berkembang Sangat Baik). Peningkatan kemampuan motorik halus anak kelompok B2 dari sebelum tindakan ke tindakan siklus I mencapai 30.875\% dan peningkatan dari siklus I ke siklus II mencapai $61.1875 \%$.
Berdasarkan hasil tersebut diketahui ratarata kemampuan motorik halus anak kelompok B2 pada tindakan Siklus II skornya mencapai 366.5 atau $91.5 \%$ (Berkembang Sangat Baik/BSB).

\begin{tabular}{lcr}
\multicolumn{2}{c}{ Pelaksanaan } & \multicolumn{2}{c}{ tindakan } & yang \\
dilaksanakan dalam dua siklus & dua \\
menunjukkan & adanya & peningkatan \\
kemampuan motorik halus pada anak & kelompok B2 & TK Islam Terpadu Darul \\
Mukhlishin. & Hasil & peningkatan
\end{tabular}
kemampuan motorik halus anak kelompok B2 dari sebelum tindakan, tindakan siklus I dan tindakan siklus II tersebut disajikan melalui gambar 1 grafik berikut ini: 
anak pada TK Islam Terpadu Darul Mukhlishin.

\section{SIMPULAN}

Berdasarkan hasil penelitian dan pembahasan dapat disimpulkan bahwa kegiatan menulis diatas pasir dapat meningkatkan kemampuan motorik halus anak pada kelompok B2 TK Islam Terpadu Darul Mukhlishin. Kemampuan motorik halus yang dicapai anak kelompok B2, sebelum tindakan mencapai $30.25 \%$ dengan kategori belum baik (Belum Berkembang). Pada tindakan siklus I mencapai $61.125 \%$ dengan kriteria cukup (Berkembang Sesuai Harapan). Pada tindakan siklus II mencapai 91.5\% dengan kategori baik (Berkembang Sangat Baik). Peningkatan kemampuan motorik halus anak kelompok B2 dari sebelum tindakan ke tindakan siklus I mencapai 30.875\% dan peningkatan dari siklus I ke siklus II mencapai $61.1875 \%$. Pada pengujian hipotesis melalui uji-t dengan taraf signifikan 5\% memperlihatkan bahwa nilai thitung $\geq$ ttabel yaitu $22.23 \geq 2.093$. maka dapat disimpulkan bahwa Ho ditolak dan Ha diterima yaitu kegiatan menulis di atas pasir dapat meningkatkan kemampuan motorik halus anak pada TK Islam Terpadu Darul Mukhlishin kelompok B2.

\section{DAFTAR PUSTAKA}

Arikunto, S. (2002). Metodologi Penelitian. Jakarta: Rineka Cipta.

Arikunto, S. (2006). Dasar-Dasar Evaluasi Pendidikan. Jakarta: Bumi Aksara.

Arikunto, S. (2010). Prosedur Penelitian Suatu Pendekatan Praktek. Jakarta: Rineka Cipta.
Atkinson, R. L., Richard, C. A. (2009). Pengantar Psikologi Edisi 8. Jakarta: Erlangga

Departemen Pendidikan Nasional. (2000). Permainan Membaca dan Menulis di Taman Kanak-Kanak. Jakarta: Departemen Pendidikan Nasional

Departemen Pendidikan Nasional. (2007). Pedoman Pengembangan Fisik/Motorik di Taman Kanak-Kanak. Jakarta: Departemen Pendidikan Nasional

Gardner, H. (2003). Multiple Intelegence (Kecerdasan Majemuk) Teori dan Praktek. Jakarta: Interaksara.

Hurlock, E. B. (1998). Perkembangan Anak Jilid 1. Jakarta: Erlangga

Maghfirah, S. (2019). Pemanfaatan Barang Bekas dalam Meningkatkan Kemampuan Motorik Halus Anak. Atfaluna: Journal of Islamic Early Childhood Education, 2(1), 48-52. https://doi.org/10.32505/atfaluna.v2i1.9 38

Markam, S. (1987). Pengenalan Belajar dan Disfungsi Minimal Otak. Jakarta: FKUI

Mudjito. A. K. (2007). Pedoman Bidang Pengembangan Pembiasaan di Taman Kanak-Kanak. Jakarta: Departemen Pendidikan Nasional

Riduan. (2007). Belajar Mudah Penelitian Untuk Guru-Karyawan dan Peneliti Pemula. Bandung: Alphabet.

Russel., W. (1986). Autism an Executive Disorders. Oxford: Oxford University Press

Santrock, J. W. (1995). Life Span Development (Perkembangan Masa Hidup). Jakarta: Erlangga 
Saputra, $\quad$ R.

PengertianMotorikHalus

Bandung: BumiAksara

Sidabutar, R. R., \& Siahaan, H. (2019).

Peningkatan Motorik Halus Anak Usia

Dini melalui Pemanfaatan Media Daun dalam Kegiatan Pembelajaran.

Atfaluna: Journal of Islamic Early Childhood Education, 2(1), 39-47. https://doi.org/10.32505/atfaluna.v2i1.9 30

Subana, dkk. (2005). Statistik Pendidikan. Bandung: Pustaka Setia.

Sugiyono. (2011). Metode Penelitian Kuantitatif, Kualitatif dan R\&D. Bandung: Alfabet
Sugiyono. (2012). Memahami Penelitian Kualitatif. Bandung: CV. Alfabeta

Suyadi. (2009). Psikologi Belajar PAUD. Yogyakarta: PT. Pustaka Insane Madani

Suyanto. (2005). Konsep Dasar Anak Usia Dini. Jakarta: Departemen Pendidikan Nasional

Undang-Undang Republik Indonesia Nomor 20 Tahun 2003 tentang Sistem Pendidikan Nasional.

Yudha. M. S. \& Rudyanto. (2005). Pembelajran Kooperatif untuk Meningkatkan Keterampilan Anak Taman Kanak-Kanak. Jakarta: Departemen Pendidikan Nasional 